\title{
LOCAL MECHANICAL PROPERTIES OF IRRADIATED CROSS-LINKED HDPE
}

\author{
LOKALNE MEHANSKE LASTNOSTI PREČNO VEZANEGA HDPE \\ PO MOČNEM RADIOAKTIVNEM OBSEVANJU $\beta$
}

\author{
Lenka Hýlová, David Manas, Miroslav Manas, Lenka Gajzlerova, Ales Mizera \\ Tomas Bata University in Zlin, T. G. Masaryk Square 5555, 76001 Zlin, Czech Republic \\ hylova@utb.cz \\ Prejem rokopisa - received: 2017-07-01; sprejem za objavo - accepted for publication: 2017-10-11
}

doi:10.17222/mit.2017.096

\begin{abstract}
Using high doses of beta radiation for high-density polyethylene (HDPE) and its influence on the changes in the micromechanical properties of the surface layer has not been studied in detail so far. Specimens of HDPE were made with the injectionmoulding technology and irradiated with high doses of beta radiation $(0,132,165$ and 198) kGy. The changes in the micromechanical properties of the surface layer were evaluated using an ultra nano-hardness test. The results of the measurements showed a considerable increase in the micromechanical properties (indentation hardness, indentation elastic modulus) when high doses of beta radiation are used. The aim of this paper is to study the effect of ionizing radiation at different doses on the ultra nano-hardness of the surface layer of HDPE and compare these results with those for non-irradiated samples. The study was carried out due to the ever-growing use of this type of polymer HDPE.
\end{abstract}

Keywords: high-density polyethylene (HDPE), surface layer, mechanical properties, ultra nano-hardness

Avtorji prispevka so raziskovali vpliv močnega radioaktivnega sevanja $\beta$ na mikromehanske lastnosti površinskih plasti polietilena z veliko gostoto (HDPE), kar do sedaj ni natančneje raziskoval še nihče. Vzorce HDPE so izdelali s tehnologijo injekcijskega brizganja in jih obsevali z visokimi dozami $(0,132,165$ in 198) kGy radioaktivnega sevanja $\beta$. Mikromehanske lastnosti površinskih plasti obsevanih vzorcev so določili z merjenjem ultra nanotrdote. Rezultati meritev so pokazali znatno povišanje mikromehanskih lastnosti (nanotrdote in elastičnega modula vtiskovanja) močno obsevanih vzorcev. Namen tega prispevka je prikazati vpliv radioaktivnega sevanja $\beta$ različnih jakosti na površinske plasti HDPE in primerjavo z neobsevanim vzorcem. Raziskava je bila izdelana zaradi vse večje uporabe tega polimernega materiala v pogojih radioaktivnega sevanja.

Ključne besede: polietilen z veliko gostoto (HDPE), površinska plast, mehanske lastnosti, ultra nanotrdota

\section{INTRODUCTION}

The irradiation cross-linking of thermoplastic materials via an electron beam or cobalt 60 (gamma rays) proceeds separately after the processing. The cross-linking level can be adjusted with the irradiation dosage and often by means of a cross-linking booster.

The main deference between $\beta$ - and $\gamma$-rays (Figure 1) is in their different abilities of penetrating the irradiated material; $\gamma$-rays have a high penetration capacity. The penetration capacity of electron rays depends on the energy of the accelerated electrons.

Thermoplastics used for the production of various types of products have very different properties. Standard polymers that are easily obtained at favourable price conditions belong to the main class. The disadvantage of standard polymers relates to both the mechanical and thermal properties. The group of standard polymers is the most considerable one and its share in the production of all polymers is as high as $90 \%$.

Engineering polymers are a very important group of polymers, exhibiting much better properties in comparison to those of standard polymers. Both mechanical and thermal properties are much better than in the case of standard polymers. The production of these types of polymers accounts for less than $1 \%$ of all the polymers. $^{1-6}$

High-performance polymers have the best mechanical and thermal properties but their share in the production and use of all the polymers is less than $1 \%$.

The present work deals with the influence of beta irradiation on the mechanical properties of the surface layer of injection-moulded HDPE.

\section{EXPERIMENTAL PART}

For this experiment, high-density polyethylene (HDPE) DOW - HDPE 25055E, the DOW Chemical Company, USA (unfilled, HDPE) - was used. Irradiation was carried out at the company BGS Beta-GammaService GmbH \& Co, KG, Germany, using electron rays, an electron energy of $10 \mathrm{MeV}$, and doses of $(0,132,165$ and 198) $\mathrm{kGy}$ in air at ambient temperature.

Samples (Figure 2) were made using the injectionmoulding technology on an injection-moulding machine Arburg Allrounder 420C. The processing temperature was $245-295{ }^{\circ} \mathrm{C}$, the mould temperature was $85^{\circ} \mathrm{C}$, the injection pressure was $80 \mathrm{MPa}$ and the injection rate was $45 \mathrm{~mm} / \mathrm{s}^{7-11}$ 


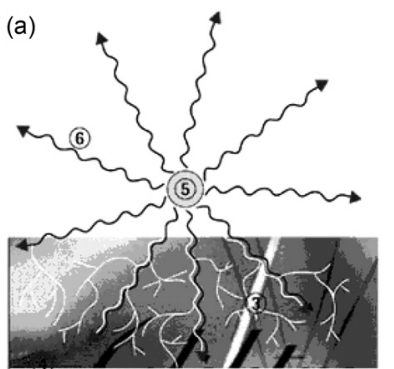

(b)

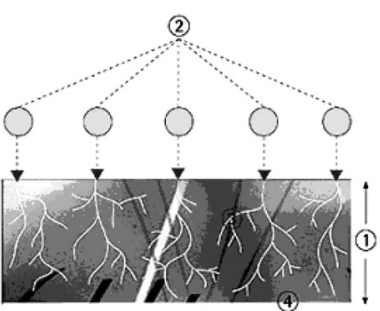

Figure 1: a) design of gamma rays and b) electron rays: 3 - secondary electrons, 4 - irradiated material, 5 - encapsulated Co-60 radiation source, 6 - gamma rays, b) 1 - penetration depth of electrons, 2 primary electrons, 3 - secondary electrons, 4 - irradiated material

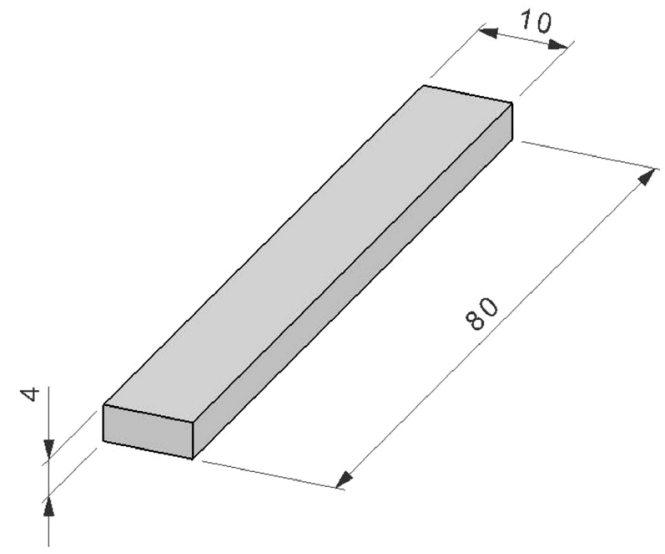

Figure 2: Dimensions of a sample

A nanoindentation test was done using an ultra nanoindentation tester (UNHT), CSM Instruments (Switzerland), according to the CSN EN ISO 14577. The load and unload speed was $1000 \mathrm{~N} / \mathrm{min}$. After a holding time of $90 \mathrm{~s}$ at the maximum load of $500 \mu \mathrm{N}$, the specimens were unloaded. The specimens were glued onto metallic sample holders (Figure 2). ${ }^{7-11}$

$$
H_{\mathrm{IT}}=F_{\max } / A_{\mathrm{p}}
$$

Here $H_{\mathrm{IT}}$ is the indentation hardness, $F_{\max }$ is the maximum applied force, and $A_{\mathrm{p}}$ is the projected area of contact between the indenter and the test piece determined from the force-displacement curve and the knowledge of the area function of the indenter. ${ }^{7-11}$

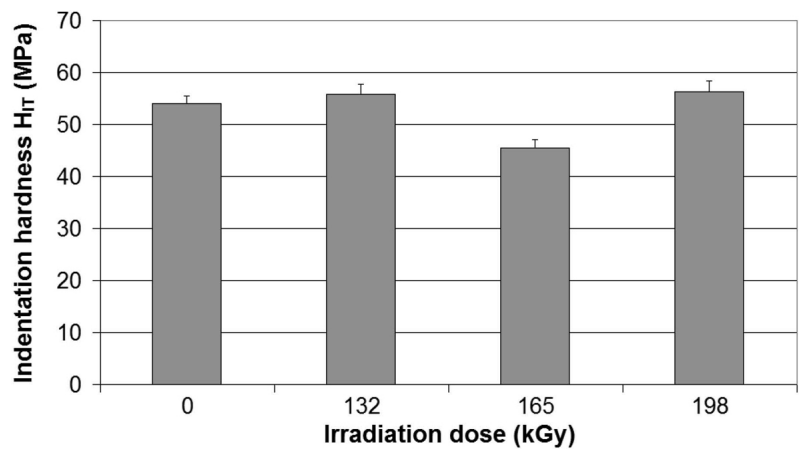

Figure 3: Indentation hardness $H_{\mathrm{IT}}$

\section{RESULTS}

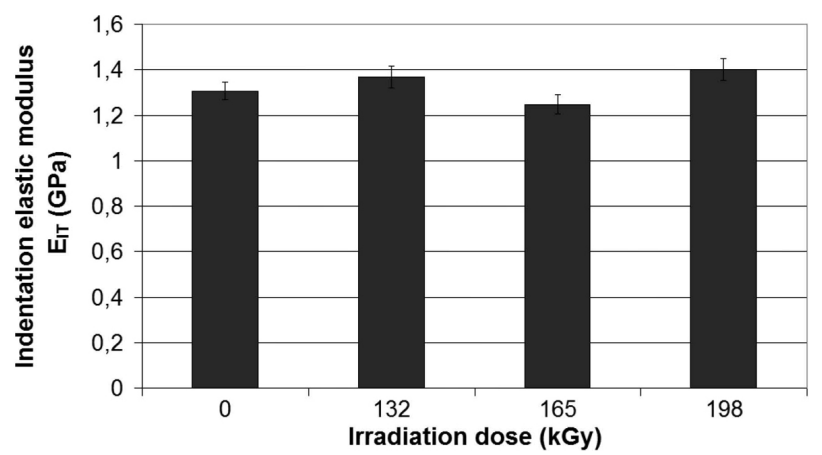

Figure 4: Indentation elastic modulus $E_{\mathrm{IT}}$

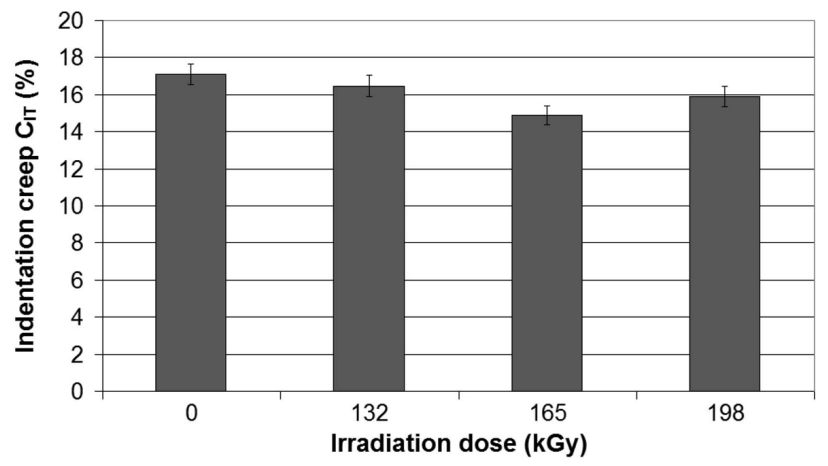

Figure 5: Indentation creep $C_{\mathrm{IT}}$

\section{DISCUSSION}

The development of the micromechanical properties of the irradiated high-density polyethylene (HDPE) was characterized with a test of the ultra nano-hardness $\left(H_{\mathrm{TT}}\right)$, as can be seen in Figure 3. The lowest value (45 MPa) of the indentation hardness was found for the high-density polyethylene (HDPE) irradiated with the dose of 165 $\mathrm{kGy}$, while the highest value of the indentation hardness was found for the non-irradiated high-density polyethylene $(56 \mathrm{MPa})$. The increase in the indentation hardness at the $198 \mathrm{kGy}$ radiation dose was $4 \%$ compared to the non-irradiated high-density polyethylene (HDPE).

A similar development was recorded for the microstiffness of the specimens represented by the indentation elastic modulus $\left(E_{\mathrm{IT}}\right)$ illustrated in Figure 4. The results of the measurements show clearly that the lowest value of the indentation elastic modulus was measured for the high-density polyethylene (HDPE) (1.24 GPa) irradiated with the dose of $165 \mathrm{kGy}$, while the highest value was found for the high-density polyethylene (HDPE) irradiated with $198 \mathrm{kGy}(1.4 \mathrm{GPa})$. A significant increase in the indentation elastic modulus (7\%) was recorded at the radiation dose of $198 \mathrm{kGy}$, compared to the nonirradiated high-density polyethylene (HDPE).

Very important values were found for the indentation creep. For the materials, which creep as polymers, the basic calculation of the creep can be measured during a 
pause at the maximum force. The creep is a relative change of the indentation depth when the test force is kept constant. The results of the test of the ultra nanohardness, Figure 5, show that the highest creep value was measured at the $0 \mathrm{kGy}$ radiation dose $(17 \%)$, while the lowest creep value was found for the high-density polyethylene (HDPE) irradiated with the $165 \mathrm{kGy}$ dose (14\%). The creep decreased by $13 \%$ because of the radiation, which is a considerable increase in the surface-layer resistance.

\section{CONCLUSIONS}

This article deals with the measurements of the mechanical properties of a high-density polyethylene (HDPE) surface layer modified with beta radiation. Injection-moulded test bodies were irradiated with beta radiation using doses of $(0,132,165$ and 198) kGy. The measurements of the mechanical properties were realized with an ultra nano-hardness tester.

The measurement results show an improvement in the chosen mechanical properties. The micro-hardness of the high-density polyethylene (HDPE) surface layer irradiated with the $198 \mathrm{kGy}$ dose increased by $4 \%$. The rigidity of the tested surface layer represented by the modulus of elasticity increased by $7 \%$ for the sample irradiated with the $198 \mathrm{kGy}$ dose. The creep of the tested surface layer decreased from $17 \%$ for the non-irradiated sample to a value of $14 \%$ for the sample irradiated with the $165 \mathrm{kGy}$ dose.

\section{Acknowledgment}

This paper was supported by an internal grant of the TBU in Zlin, No. IGA/FT/2017/010, funded from the resources of the specific university research and by the Ministry of Education, Youth and Sports of the Czech Republic within the National Sustainability Programme, project No. LO1303 (MSMT-7778/2014) and also by the European Regional Development Fund under project CEBIA-Tech, No. CZ.1.05/2.1.00/03.0089. Special thanks goes to Dr. Michal Danek (BGS Beta-GammaService $\mathrm{GmbH} \& \mathrm{Co}, \mathrm{KG}$, Germany) for his kind assistance during the sample preparation.

\section{REFERENCES}

${ }^{1}$ A. Barlow, L. A. Hill, L. A. Meeks, Radiation processing of polyethylene, Radiat. Phys. Chem., 14 (1979), doi:10.1016/01465724(79)90114-6

${ }^{2}$ R. J. Woods, A. K. Picaev, Applied radiation chemistry: radiation processing, New York: John Wiley, 1994

${ }^{3}$ R. M. Silverstein, G. C. Bassler, T. C. Morril, Spectrometric identification of organic compounds, New York: John Wiley, 1980

${ }^{4}$ L. Chvatalova, J. Navratilova, R. Cermak, M. Raab, M. Obadal, Joint Effects of Molecular Structure and Processing History on Specific Nucleation of Isotactic Polypropylene, Macromolecules, 42 (2009), doi:10.1021/ma9005878

${ }^{5}$ D. Manas, M. Hribova, M. Manas, M. Ovsik, M. Stanek, D. Samek, The effect of beta irradiation on morfology and micro hardness of polypropylene thin layers, Thin Solid Films, 530 (2013), doi:10.1016/j.tsf.2012.09.051

${ }^{6}$ D. Manas, M. Manas, M. Stanek, M. Danek, Improvement of plastic properties, Arch. Mater. Sci. Eng., 32 (2008)

${ }^{7}$ S. Shukushima, H. Hayami, T. Ito, S. I. Nishimoto, Modification of radiation cross-linked polypropylene, Radiat. Phys. Chem., 60 (2001), doi:10.1016/S0969-806X(00)00395-9

${ }^{8}$ W. C. Oliver, G. M. Pharr, An improved technique for determining hardness and elastic modulus using load and displacement sensing indentation, J. Mater. Res., 7 (1992), doi:10.1557/JMR.1992.1564

${ }^{9}$ A. Lalande, D. Gardette, Influence of the structure on the $\gamma$-irradiation of polypropylene and on the post-irradiation effects, Nucl. Instrum. Methods Phys. Res. B, 222 (2004), doi:10.1016/j.nimb. 2004.02.012

${ }^{10}$ M. Ovsik, D. Manas, M. Manas, M. Stanek, M. Hribova, K. Kocman, D. Samek, Irradiated Polypropylene Studied by Microhardness and WAXS, Chemicke listy, 106 (2012), ISSN: 0009-2770

${ }^{11}$ E. Ragan, P. Baron, J. Dobránsky, Sucking machinery of transport for dosing granulations of plastics at injection moulding, Adv. Mat. Res., (2012), 383-390, doi:10.4028/www.scientific.net/AMR.383390.2813 